Artikel Penelitian

\title{
Karakteristik Fisik dan Kimia Gelatin dari Tulang Ikan Patin dengan Pre- Treatment Asam Sitrat
}

\section{Physical and Chemical Characteristics of Gelatin from Pangasius Catfish Bone with Pre-Treatment of Citric Acid}

Mega Pertiwi ${ }^{1 \star}$, Yoni Atma ${ }^{1}$, Apon Zaenal Mustopa ${ }^{2}$, Rizkia Maisarah ${ }^{1}$

1Jurusan Teknologi Pangan, Fakultas Bioindustri, Unversitas Trilogi, Jakarta

${ }^{2}$ Pusat Penelitian Bioteknologi, Lembaga IImu Pengetahuan Indonesia (LIPI), Bogor

Korespondensi dengan penulis (megapertiwi019@gmail.com)

Artikel ini dikirim pada tanggal 31 Maret 2017 dan dinyatakan diterima tanggal 25 Mei 2018. Artikel ini juga dipublikasi secara online melalui www.jatp.ift.or.id. Hak cipta dilindungi undang-undang. Dilarang diperbanyak untuk tujuan komersial.

Diproduksi oleh Indonesian Food Technologists® (C2018

\begin{abstract}
Abstrak
Penelitian ini bertujuan untuk melakukan ekstraksi gelatin dari tulang ikan patin menggunakan asam sitrat dan menganalisis karakteristik fisiko-kimianya. Ekstraksi gelatin melalui dua tahap yaitu tahap pre-treatment dengan asam sitrat dan ekstraksi utama dengan aquadest. Tahap pre-treatment dilakukan dengan variasi waktu yakni $24,36,48$ dan 56 jam. Tahapan ekstraksi utama dilakukan pada suhu $45,55,65$, dan $75^{\circ} \mathrm{C}$. Hasil ekstraksi dilanjutkan dengan analisis keberadaan protein gelatin dengan metode SDS-PAGE. Analisis fisiko-kimia gelatin meliputi derajat keasaman $(\mathrm{pH})$, rendemen, kekuatan gel, profil tekstur, viskositas, kadar air, kadar abu, kadar protein dan kadar lemak juga dilakukan. Hasil SDS-PGE gelatin perlakuan terbaik (yakni dengan pre-treatment 48 jam dan ekstraksi utama pada suhu $75^{\circ} \mathrm{C}$ ) diketahui memiliki bobot molekul $162 \mathrm{kDa}$. Gelatin hasil ekstraksi terbaik memiliki rendemen sebesar 6,14\%. Gelatin tulang ikan patin memiliki pH 4,46, kekuatan gel 364,19 bloom, daya kunyah sebesar $261,76 \mathrm{~g}$ dan viskositas $3,83 \mathrm{cP}$. Kadar air, kadar abu, kadar protein dan kadar lemak masingmasing berhasil diidentifikasi sebesar 7,$72 ; 0,38 ; 58,70$, dan 2,79\%. Hasil penelitian juga menunjukkan bahwa semakin tinggi suhu ekstraksi dan lamanya proses pre-treatment yang digunakan, maka bobot molekul protein menjadi semakin tinggi. Kesimpulannya, pre-treatment asam sitrat selama 48 jam dan ekstraksi utama pada suhu $75^{\circ} \mathrm{C}$, berhasil menunjukkan hasil terbaik dan dapat terkarakterisasi sifat fisik serta kimianya.
\end{abstract}

Kata kunci : gelatin, tulang ikan, ekstraksi, asam sitrat, fisiko-kimia.

\begin{abstract}
This research aimed to extract gelatin from Pangasius catfish bone using citric acid and then analyse its physicochemical characteristics. The extraction of gelatin was done in two stages soaking i.e pre-treatment with citric acid and main extraction by aquadest. Pre-treatment was done by soaking bones at 24, 36, 48 and $56 \mathrm{~h}$, then the main extraction was done by soaked leached bones in temperature $45,55,65$, and $75^{\circ} \mathrm{C}$. The gelatin from catfish bone then was analyzed the presence of protein by SDS-PAGE and its physico-chemical including $\mathrm{pH}$, yield, gel strength, texture profile, viscosity, moisture content, ash content, protein content, and fat content. Based on SDS-PAGE, fish bone gelatin had molecular weight of $162 \mathrm{kDa}$. The best extraction treatment (pre-treatment 48 $h$ and main extraction at $75^{\circ} \mathrm{C}$ ) produced $6.14 \%$ of gelatin yield. Gelatin of pangasius catfish bone had pH 4.46, gel strength of 353.76 bloom, chewing power of $261.76 \mathrm{~g}$, and viscosity of $3.83 \mathrm{cP}$. Water, ash, protein and fat content was $7.72,0.38,58.70$, and $2.79 \%$, respectively. The higher extraction temperature and the longer time for pretreatment process, the higher molecule weight of protein. As conclusion, the best treatment that was found in the sample with the pre-treatment at $48 \mathrm{~h}$ and the main extraction at $75^{\circ} \mathrm{C}$, was successfully characterized on its physicochemicals.
\end{abstract}

Keywords: gelatin, fish bone, extraction, citric acid, physico-chemical.

\section{Pendahuluan}

Gelatin merupakan protein yang diperoleh dari kulit, tulang dan jaringan serat putih (white fibrous) hewan. Hewan yang menjadi sumber gelatin utama yakni babi dan sapi. Produksi gelatin dari kulit babi mencapai $46 \%$, kulit sapi $29,4 \%$, tulang sapi $23,1 \%$ dan sumber alternatif 1,5\% (Karim dan Bhat, 2009) dari total produksi gelatin dunia. Gelatin dari kulit babi tidak diterima oleh masyarakat muslim karena diharamkan (Atma, 2016) dan tidak diterima oleh masyarakat Majusi (Atma, 2016). Selain itu, adanya kasus wabah sapi gila atau bovine spongiform encephalopathy (BSE), penyakit kuku dan mulut semakin perlu dicarinya sumber alternatif potensial untuk memperoleh gelatin (Nurul dan Sabron, 2015).

Saat ini sumber alternatif yang cukup potensial untuk produksi gelatin adalah kulit dan tulang ikan (Ratnasari et al., 2013). Penelitian sebelumnya telah dilakukan analisis gelatin pada bagian kulit dan tulang ikan antara lain; tuna, hiu, kurisi, salmon, pari, mas, ikan sturgeon, baung, kakap, kakap merah, rohu, nila, patin, beloso, catla, gelik, ikan kod, ikan mackerel, kakap merah, kurisi, nila, patin, lele, kerapu, blue whiting (sejenis ikan kod), beloso, dan ikan gelik (Atma, 2017). Hampir sepertiga dari berat ikan berasal kulit dan tulangnya, bahkan menurut Shyni et al. (2014), 
penyumbang terbesar berat badan ikan berasal dari tulang dan kulit, akan tetapi limbah tulang ikan dibuang dan tidak dimanfaatkan (Atma, 2016) .

Saat ini pemanfaatan tulang ikan sebagai sumber alternatif gelatin sudah banyak diteliti. Hasil penelitian sebelumnya menyatakan bahwa gelatin dari tulang ikan yang hidup di perairan hangat memiliki kualitas fisik seperti kekuatan gel dan viskositas yang lebih baik dibandingkan dari tulang ikan yang hidup di perairan dingin (Atma, 2017). Penelitian yang dilakukan oleh Mahmoodani et al. (2014) menunjukkan bahwa kualitas gelatin tulang ikan patin memiliki karakteristik fisik yang menyerupai gelatin sapi. Hasil penelitian yang dilakukan Mahmoodani et al. (2014) yaitu mengekstrak gelatin tulang ikan patin menggunakan $\mathrm{HCl}$, didapatkan kadar air sebesar 9,2\%, kadar abu 2,6\%, kadar lemak $0,96 \%$, dan kadar protein $87,3 \%$. Hasil studi yang dilakukan Atma (2017) menunjukan bahwa gelatin dari tulang ikan patin juga memiliki kadar abu sesuai dengan standar. Kadar abu dan kadar air merupakan parameter mutu kimia penting gelatin, parameter mutu fisik dan kimia gelatin tulang ikan dipengaruhi oleh cara ekstraksinya (Atma dan Ramdhani, 2017).

Ektraksi gelatin tulang ikan biasanya dilakukan dengan dua tahap yakni pre-treatment dengan asam atau basa dan main extraction dengan air hangat (Atma dan Ramdhani, 2017). Menurut Mariod and Adam (2013) ekstraksi dengan asam sitrat lebih disukai, aman dan tidak membutuhkan tahapan penanganan lainnya dalam produksi gelatin untuk bahan pangan. Di Indonesia, tulang ikan yang sudah diteliti proses ekstraksinya dengan menggunakan asam sitrat adalah tulang ikan cucut (Indrialaksmi, 2000), bandeng (Fatimah dan Jannah, 2009), tenggiri (Adiningsih dan Purwanti, 2015), lele dumbo (Iqbal et al., 2015), pari mondol (Santoso et al., 2015) dan kakap merah (Syahraeni et al., 2017). Data menunjukan menggunakan asam sitrat dalam ekstraksi tulang ikan patin belum dilakukan sebelumnya. Oleh karena itu, tulang ikan patin dapat dijadikan sumber alternatif paling potensial untuk dikembangkan.

Penelitian ini dilakukan untuk mengekstraksi gelatin tulang ikan patin menggunakan asam sitrat pada tahapan pre-treatment dan kemudian menganalisis karakteristik fisik serta sifat kimianya. Analisis fisik meliputi, kekuatan gel, profil tekstur, viskositas dan $\mathrm{pH}$, sedangkan analisis sifat kimia meliputi kadar abu, kadar air, kadar protein dan kadar lemak. Karakteristik fisik dan kimia gelatin yang diperoleh dari penelitian ini dibandingkan dengan gelatin dari tulang ikan lainnya dan gelatin komersial.

Hasil penelitian ini juga ditujukan untuk mengetahui kondisi perlakuan terbaik untuk ekstraksi gelatin dari tulang ikan patin menggunakan asam sitrat dan menganalisis karakteristik fisiko-kimia gelatin yang dihasilkan. Manfaat penelitian ini adalah mendapatkan gelatin yang memiliki karakteristik fisiko-kimia yang sesuai standar dan menggunakan pelarut kimia yang lebih aman.

\section{Materi dan Metode \\ Materi}

Bahan-bahan yang digunakan untuk ekstraksi gelatin adalah tulang ikan patin yang diperoleh dari CV Karunia Mitra Makmur daerah Cikampek, Jawa Barat, asam sitrat dan aquadest. Bahan kimia yang digunakan untuk analisis proksimat meliputi larutan heksana (Merck, Germany), kertas saring bebas lemak, kapas, larutan $\mathrm{H}_{2} \mathrm{SO}_{4}$ pekat (Merck, Germany), larutan $\mathrm{NaOH}$ (Merck, Germany), indikator BCG-MM (Bromocresol Green-Merah Meti) (SCIENCE Company, USA), larutan standar $\mathrm{HCl}$ (Merck, Germany) dan bahan untuk konfirmasi gelatin dengan SDS-PAGE (Sodium Dodecyl Sulphate Polyacrylamide Gel Electrophoresis) adalah Tris $\mathrm{HCl}$ (Bio Basic Inc, USA), akrilamid (Bio Basic Inc, USA), TEMED (Sigma, USA), amonium persulfat (APS) (MP biomedicals, Sweden) dan protein marker (SMOBIO, Taiwan).

Alat-alat yang digunakan dalam ekstraksi gelatin meliputi timbangan, pisau, Meat Cutter (Fomac, China), WaterBath (Faithful, China), nampan, kertas saring, kain blacu, food dehydrator (Ecalibur, USA), shaker, sentrifugasi (Hitachi, Japan), label, erlenmeyer, gelas piala, mikropipet dan gelas ukur. Alat-alat yang digunakan untuk analisa adalah neraca analitik, oven (Memmert, German), tanur (Lenton Furnaces, UK), labu kjeldahl, sokhlet, Texture Analyzer (Brookfield CT3, USA), Viscometer LV D-II+Pro (Brookfield, USA), $\mathrm{pH}$ meter (Agilent Technologies 3200P, USA), perangkat elektroforesis SDS-PAGE (ATTO AE-6500, Japan), cawan porselen, cawan petri, erlenmeyer, mortar, mikropipet, botol schoot, labu ukur, gelas ukur, mikropipet dan gelas piala.

\section{Metode}

Penelitian ini dilakukan dari bulan September 2017 sampai bulan Maret 2018. Tempat dilakukannya penelitian adalah Laboratorium Biokimia Universitas Trilogi, Pusat Penelitian Bioteknologi LIPI dan Balai Penelitian Pasca Panen Bogor. Penelitian ini dibagi menjadi dua tahap. Tahap pertama, yaitu proses ekstaksi gelatin dari tulang ikan patin dan dilakukan analisis keberadaan protein gelatin dengan metode SDS-PAGE. Tahap kedua, yaitu analisis fisiko-kimia gelatin meliputi derajat keasaman $(\mathrm{pH})$, rendemen, kekuatan gel, profil tekstur, viskositas kadar air, kadar abu, kadar protein dan kadar lemak.

\section{Ekstraksi Gelatin Tulang Ikan Patin}

Produksi gelatin dari tulang ikan patin mengacu pada penelitian Atma (2017) tahapan produksinya meliputi proses degreasing yaitu proses penghancuran limbah tulang ikan patin menggunakan meat cutter. Selanjutnya dilakukan tahapan pre-treatment untuk menghilangan kalsium dan garam-garam mineral dari tulang dengan cara perendaman dalam larutan asam sitrat $1 \%$ selama 24, 32, 48 dan 56 jam. Perbandingan tulang dan larutan asam sitrat adalah 1:4. Setelah itu dilakukan pemisahan larutan asam sitrat dengan tulang ikan yang diperoleh yang disebut ossein. Tulang ikan patin yang telah menjadi ossein kemudian dilakukan 
pembilasan dengan aquadest sampai $\mathrm{pH}$ netral (6-7). Main extraction dilakukan dengan menggunakan aquadest pada suhu $45,55,65$, dan $75^{\circ} \mathrm{C}$ selama 5 jam (perbandingan ossein : aquadest $=1: 4$ ).

Filtrat hasil tahap ekstraksi dipisahkan dari larutan pengekstrak menggunakan kertas saring, selanjutnya di analisa keberadaan protein gelatin pada filtrat menggunakan Sodium Dodecyl Sulphate Polyacrylamide Gel Electrophoresis (SDS PAGE) atau sebelum mulai pengujian SDS filtrat di simpan di dalam refrigerator. Hasil ekstraksi terbaik yang telah dikonfirmasi keberadaan proteinnya melalui SDS PAGE dilakukan produksi skala besar untuk analisis fisikokimia. Karakteristik fisik gelatin yang dianalisis terdiri dari analisis nilai $\mathrm{pH}$, kekuatan gel, profil tekstur dan viskositas, sedangkan karakteristik kimia gelatin yang dianalisis yaitu kadar proksimat.

\section{Analisis SDS PAGE}

Analisis bobot molekul gelatin tulang ikan patin dilakukan menggunakan SDS PAGE (Walker, 2009) dengan modifikasi. Protein marker yang digunakan yaitu molecul weight (MW) 5-245 kDa. Sampel dimasukkan sebanyak $10 \mu \mathrm{l}$ ke dalam tube kecil (tube khusus PCR) dan dicampurkan dengan $10 \mu$ loading protein selanjutnya didenaturasi pada suhu $100^{\circ} \mathrm{C}$ selama 5 menit. Sebelum dimasukkan ke dalam sumur pada gel elektroforesis, campuran sampel dan loading protein yang telah didenaturasi dimasukkan dalam lemari pendingin. Gel terdiri dari 2 bagian yaitu separating gel dan konsentrat gel. Komposisi separating dan konsentrat (stacking) gel untuk SDSPAGE dapat dilihat pada Tabel 3. Separating gel dibuat terlebih dahulu dan berada pada bagian bawah, sedangkan konsentrat gel berada pada bagian atas.

Gel dibiarkan mengering tetapi sebelumnya sumur pada gel telah dibuat. Gel dipasang pada perangkat gel elektroforesis dengan posisi berdiri dan direndam dengan buffer elektroforesis. Kemudian marker dan sampel dimasukkan masing-masing sebanyak $7 \mu$ l pada sumur gel. Running elektroforesis menggunakan voltase $110 \mathrm{~V}$ dilakukan selama \pm 40 menit. Setelah itu gel dilepaskan dan direndam dalam larutan commasie blue selama 30 menit. Gel yang telah direndam dalam larutan commasie blue diletakkan pada roker. Tahap selanjutnya gel dibilas dengan aquadest dan kemudian direndam kembali dalam larutan destaining selama satu malam. Band atau pita protein dengan berat molekul berbeda akan terpisah. Hasil yang diperoleh didokumentasikan melalui alat komputer dan multiscan.

\section{Analisis Fisiko-Kimia}

Analisis rendemen diperoleh dari perbandingan berat kering gelatin yang dihasilkan dengam berat ossein (Mahmoodani et al., 2014). Analisis derajat keasaman $(\mathrm{pH})$, dilakukan dengan menggunakan sampel gelatin sebanyak $10 \mathrm{~g}$ yang dilarutkan dengan aquades hingga mencapai volume $100 \mathrm{ml}$. Pengukuran $\mathrm{pH}$ larutan gelatin menggunakan $\mathrm{pH}$ meter yang telah dikalibrasi dengan larutan standar $\mathrm{pH} 4$ dan 7. Analisis kekuatan gel, dilakukan dengan menggunakan texture analyzer menurut metode peneliti sebelumnya (GMIA, 2012). Gelatin cair yang telah melalui proses ekstraksi dan penyaringan dengan kertas saring dimasukan dalam refrigerator pada suhu $10^{\circ} \mathrm{C}$ selama $17 \pm 2$ jam (gelatin cair telah membentuk gel), kemudian diukur kekuatan gel. Kekuatan gel diukur dengan menggunakan alat Texture Analyzer Brookfield. Alat ini menggunakan probe dengan luas $0,1923 \mathrm{~cm}^{2}$. Sampel diletakkan dibawah probe dan dilakukan penekanan dengan beban $97 \mathrm{~g}$. Tinggi kurva kemudian diukur dengan menggunakan jangka sorong. Perhitungan kekuatan gel diukur terlebih dahulu dengan menghitung D atau dyne $/ \mathrm{cm}^{2}$ yang didapatkan dengan menggunakan rumus hasil perkalian antara tinggi kurva/beban (dalam g) dan konstanta (yaitu 0,07) yang kemudian dikalikan 980. Kekuatan gel (bloom) didapat dari penambahan 20 dengan $2,98 \times 10^{-3}$ yang kemudian dikalikan dengan nilai $D$.

\section{Analisis Profil Tekstur}

Analisis profil tekstur sampel gelatin yang digunakan sama dengan kekuatan gel yang digunakan. Uji analisis profil tekstur dilakukan dengan menggunakan Texture Analyzer menggunakan probe TA5 dengan diameter plate $75 \mathrm{~mm}$. Nilai tekanan maksimal yaitu 40\%. Karakteristik tekstur gelatin meliputi kekerasan (hardness), kekenyalan (gumminess), dan daya kunyah (chewiness). Prinsip dan penggunaan Texture Profile Analysis (TPA) dengan kecepatan probe yang diatur $2 \mathrm{~mm} / \mathrm{s}$ dan sampel ditekan sampai 30\% tinggi awalnya. Deformasi target diatur $5 \mathrm{~mm}$. TPA adalah memberikan gaya tekan terhadap produk sebanyak dua kali dimana alat tersebut sebagai stimulasi pada saat proses pengunyahan. Kekerasan (hardness) merupakan kerja yang diperlukan agar mampu menimbulkan deformasi pada suatu bahan. Kohesivitas merupakan rasio dari area tekanan positif pada penekanan pertama dan kedua. Kekenyalan adalah kepadatan yang bertahan sepanjang pengunyahan atau energi yang dibutuhkan untuk menghancurkan makanan semipadat ke keadaan siap ditelan. Perhitungan kekenyalan diperoleh dari perhitungan kekerasan dikalikan dengan kohesivitas. Elastisitas (springiness) merupakan jarak dimana makanan kembali pada tinggi mula-mula selama akhir gigitan pertama dan gigitan kedua. Daya kunyah (chewiness) adalah energi yang dibutuhkan untuk mengunyah makanan hingga siap ditelan. Perhitungan daya kunyah dapat diperoleh menggunakan rumus perkalian antara kekenyalan dan elastisitas (GMIA, 2012).

\section{Analisis Viskositas}

Analisis viskositas dilakukan menggunakan viscometer Brookfield (GMIA, 2012). Larutan gelatin dengan konsentrasi $6,67 \%$ (b/b) disiapkan dengan aquades (7 g gelatin ditambah $105 \mathrm{ml}$ aquades) kemudian larutan diukur viskositasnya dengan menggunakan alat Viscometer Brookfield. Pengukuran dilakukan pada suhu $60^{\circ} \mathrm{C}$ dengan laju geser $60 \mathrm{rpm}$ 
menggunakan spindel. Hasil pengukuran dikalikan dengan faktor konversi. Pengujian ini menggunakan spindel SC4-31 dengan faktor konversinya adalah satu, nilai viskositas dinyatakan dalam satuan centipoise (cP).

\section{Analisis Kadar Air}

Analisis kadar air menggunakan metode oven (AOAC 1995). Cawan aluminium dikeringkan dalam oven selama 15 menit dengan suhu $100^{\circ} \mathrm{C}$. Kemudian didinginkan dalam desikator selama 10 menit dan ditimbang. Sampel sebanyak 1-2 g dimasukkan ke dalam cawan yang telah diketahui beratnya, lalu dikeringkan dalam oven pada suhu $105^{\circ} \mathrm{C}$ selama 5 jam sampai tercapai berat konstan. Selanjutnya cawan beserta isinya didinginkan dalam desikator selama 10 menit dan ditimbang. Perhitungan kadar air dilakukan dengan melakukan perbandingan berat sebelum dan setelah dilakukan pengovenan dalam satuan persen.

\section{Analisis Kadar Abu}

Analisis kadar abu dilakukan menggunakan metode tanur (AOAC 1995). Cawan porselen dikeringkan dalam oven bersuhu $100^{\circ} \mathrm{C}$, kemudian didinginkan dalam desikator dan ditimbang. Sebanyak satu gram sampel ditimbang dan dimasukkan ke dalam cawan porselen. Selanjutnya sampel dilakukan pengabuan di dalam tanur listrik pada suhu $550^{\circ} \mathrm{C}$ selama 5-6 jam atau sampai terbentuk abu. Sampel kemudian didinginkan dalam desikator dan ditimbang. Perhitungan kadar abu dilakukan dengan menghitung perbandingan berat sebelum dan setelah dilakukan proses tanur.

\section{Analisis Kadar Lemak}

Analisis kadar lemak dilakukan menggunakan metode ekstraksi soxhlet (AOAC, 1995). Labu lemak yang akan digunakan dikeringkan dalam oven bersuhu $105 \mathrm{C}$, lalu didinginkan dalam desikator dan ditimbang. Sebelum pengukuran kadar lemak, sampel yang telah ditimbang $1 \mathrm{~g}$ dihidrolisis terlebih dahulu. Hasil hidrolisis kemudian disaring dan dibungkus dengan selongsong kemudian disumbat dengan kapas dan dimasukan ke dalam alat ekstraksi (soxhlet) yang dihubungkan dengan kondensor dan labu lemak. Selanjutnya diekstraksi selama 4 jam. Labu lemak yang berisi lemak hasil ekstraksi dikeringkan dalam oven duhu $105^{\circ} \mathrm{C}$ hingga 5 jam, setelah itu didinginkan dalam desikator dan ditimbang. Berat lemak dihitung dengan menggunakan rumus perbandingan berat awal dan akhir dalam satuan persen.

\section{Analisis Kadar Protein}

Analisis protein dilakukan menggunakan metode semimikro-kjeldahl (AOAC, 1995). Sejumlah kecil sampel yaitu sekitar 0,5 g ditimbang dan dimasukkan ke dalam labu kjeldahl $30 \mathrm{ml}$. Kemudian ditambahkan $0,9 \mathrm{~g} \mathrm{~K}_{2} \mathrm{SO}_{4}, 40 \mathrm{mg} \mathrm{HgO}$, dan $2 \mathrm{ml} \mathrm{H}_{2} \mathrm{SO}_{4}$. Jika bobot sampel lebih dari $15 \mathrm{mg}$, ditambahkan $0,1 \mathrm{ml} \mathrm{H}_{2} \mathrm{SO}_{4}$ untuk setiap $10 \mathrm{mg}$ bahan organik di atas $15 \mathrm{mg}$. Sampel dididihkan selama 1-1,5 jam sampai cairan menjadi jernih. Larutan kemudian dimasukkan ke dalam alat destilasi, dibilas dengan akuades, dan ditambahkan $10 \mathrm{ml}$ larutan $\mathrm{NaOH} 30 \%$. Gas $\mathrm{NH}_{3}$ yang dihasilkan dari reaksi dalam alat destilasi ditangkap oleh $\mathrm{H}_{3} \mathrm{BO}_{3}$ dalam erlenmeyer yang telah ditambahkan 3 tetes indikator (campuran 2 bagian merah metil $0,2 \%$ dalam alkohol dan 1 bagian methylene blue $0,2 \%$ dalam alkohol). Kondensat tersebut kemudian dititrasi dengan $\mathrm{HCl} \mathrm{0,1}$ $\mathrm{N}$ yang sudah distandardisasi hingga terjadi perubahan warna kondensat menjadi abu-abu. Penetapan blanko dilakukan dengan metode yang sama seperti penetapan sampel. Kadar protein dihitung dengan melakukan perhitungan selisih volume titrasi dan blanko dikalikan normalitas $\mathrm{HCl}$ dan 0,014 , faktor konversi gelatin (yaitu 5,55), faktor pengenceran yang dibagi dengan bobot sampel dikalikan $100 \%$

\section{Hasil dan Pembahasan}

\section{Ekstraksi Gelatin Tulang Ikan Patin}

Tahap awal dilakukan proses produksi gelatin dari tulang ikan patin dan dikerjakan analisis pendeteksian protein gelatin menggunakan SDS PAGE. Proses produksi gelatin tulang ikan patin diawali dengan pengumpulan tulang ikan patin mentah yang diambil dari hasil samping (limbah) pengolahan ikan dari CV Karunia Mitra Makmur daerah Cikampek, Jawa Barat. Kemudian bahan baku tulang ikan yang didapat dilakukan proses degreasing, yaitu proses penghilangan daging, kotoran, dan lemak yang masih menempel pada tulang ikan. Proses ini dilakukan pada suhu $80^{\circ} \mathrm{C}$ selama 30 menit, hingga sisa daging dapat terpisah dari tulang dan penggunaan suhu tersebut sesuai dengan titik kelarutan dari lemak dan suhu koagulasi albumin, yaitu berkisar antara $32-80^{\circ} \mathrm{C}$. Penggunaan suhu lebih dari $80^{\circ} \mathrm{C}$ dapat mengurangi banyaknya kolagen yang dihasilkan. Waktu 30 menit pada proses degreasing merupakan waktu yang optimum untuk mengurangi jumlah lemak yang terdapat pada tulang. Setelah itu tulang yang telah dibersihkan disimpan di freezer selama \pm 12 jam untuk mengeringkan tulang setelah proses degreasing agar lebih mudah dihancurkan dengan meat cutter (Atma dan Rhamdani, 2017).

Tulang ikan yang telah dibersihkan dari daging, kotoran dan lemak kemudian dikeringkan sebelum dihancurkan menggunakan meat cutter. Pengecilan ukuran tulang dilakukan sebelum proses pre-treatment dan main extraction. Pengecilan ukuran tulang bertujuan untuk memperluas bidang permukaan sehingga pada proses pre-treatment dan ekstraksi utama, reaksi berlangsung lebih cepat. Pengecilan ukuran tulang ikan patin pada penelitian ini menggunakan meat cutter yang berbentuk seperti tabung besar yang didalamnya terdapat mata pisau untuk menghancurkan tulang. Setelah proses pengecilan tulang ikan, proses selanjutnya adalah proses pre-treatment.

Pre-treatment merupakan proses penghilangan kalsium dan garam-garam mineral yang terdapat di dalam tulang sehingga tulang yang dihasilkan menjadi lunak atau disebut ossein yang terdapat kolagen 
didalamnya. Selama proses berlangsung tulang ikan patin di aduk menggunakan shaker. Proses pretreatment dilakukan menggunakan larutan asam sitrat $1 \%$ dengan lama pre-treatment 24, 32, 48 dan 56 jam. Pada perendaman lebih dari 24 jam larutan asam sitrat diganti setiap harinya (Atma dan Ramdhani, 2017).

Penggunaan larutan pre-treatment biasanya menggunakan larutan $\mathrm{HCl}$ dengan rentang konsentrasi $\mathrm{HCl} 2-6 \%$ dan lama perendaman yang relatif singkat yaitu 2-3 hari (Haris, 2008). Proses pre-treatment pada penelitian menggunakan asam sitrat 1\%. Tahapan selanjutnya adalah proses main extraction menggunakan berbagai perlakuan suhu, yaitu 45,55 , 65 dan $75^{\circ} \mathrm{C}$ selama 5 jam. Perlakuan pada berbagai suhu untuk mengetahui suhu optimal ekstraksi protein dalam tulang ikan patin. Proses ekstraksi ini terjadi konversi dari kolagen menjadi gelatin. Waktu ekstraksi utama selama 5 jam merupakan waktu optimum, karena jika lebih dari 5 jam maka ossein akan hancur dan larut bersama aquadest (Rahayu dan Fithriyah, 2015). Larutan gelatin yang telah dihasilkan kemudian disaring menggunakan kertas saring. Setelah itu, dilakukan identifikasi bobot molekul menggunakan SDS-PAGE.

\section{Analisis Bobot Molekul Gelatin dengan SDS-PAGE}

Hasil yang didapatkan dari elektroforesis yaitu berupa pita-pita protein yang terpisahkan berdasarkan perbedaan berat molekulnya yang setara dengan panjang rantai protein. Migrasi pita protein dalam SDS PAGE berbanding terbalik dengan berat molekulnya (panjang pita), maka semakin besar berat molekul produk gelatin semakin lambat migrasinya sehingga posisinya pada elektroforegram semakin di atas. Berat molekul gelatin berbeda-beda, bobot molekul gelatin rata-rata berkisar mulai dari 50.000-200.000 Da atau lebih (Haris, 2008).

Terdapat 16 sampel yang di running menggunakan SDS PAGE. Hasil running memperlihatkan adanya pita protein dari berbagai perlakuan dengan lama pre-treatment dan suhu main extraction. Tujuan analisis SDS PAGE yaitu mengetahui bobot molekul protein yang terkandung disetiap perlakuan sampel. Pita protein yang paling terlihat jelas yaitu pada waktu pre-treatment 48 jam dengan suhu main extraction $75^{\circ} \mathrm{C}$. Hasil analisis SDS PAGE dapat dilihat pada Figur 1 dan 2.

Pita protein pada sampel $1,2,3$, dan 4 sangat tipis yang terlihat, tetapi pita protein mulai sedikit terlihat pada sampel 5, 6, 7 dan 8, dapat dilihat pada Gambar 1. Hal ini dikarenakan pada sampel 1, 2, 3 dan 4 menggunakan suhu minimum yaitu $45^{\circ} \mathrm{C}$ dan protein dalam tulang ikan patin tidak terdenaturasi (Atma dan Ramdhani, 2017). Pada sampel nomor 6 dan 8 pita yang terlihat diatas $100 \mathrm{kDa}$, tetapi pita protein terlalu tipis. Sampel nomor 13 dan 14 bobot molekul dibawah $75 \mathrm{kDa}$ yaitu $38 \mathrm{kDa}$. Sampel nomor 12 dan 16 terdapat pita protein diatas $100 \mathrm{kDa}$ yaitu $143 \mathrm{kDa}$, tetapi tidak terlihat jelas, pita protein yang terlihat jelas berada pada sampel 15 yaitu dengan waktu pre-treatment selama 48 jam dan suhu ekstraksi utama $75^{\circ} \mathrm{C}$. Pita protein pada sampel 15 memiliki bobot molekul yang cukup tinggi yaitu $162 \mathrm{kDa}$. Bobot molekul tersebut menunjukkan keberadaan rantai $\beta$-sheet (160-250 kDa) dapat dilihat pada Gambar 2. Penelitian Mahmoodani et al. (2014) tentang ekstraksi gelatin tulang ikan patin menggunakan asam klorida menunjukkan bahwa berat molekul gelatin berada pada kisaran $>97-120 \mathrm{kDa}$ termasuk ikatan $a$, sedangkan ikatan $\beta$ dan $\gamma$ berada pada $200-300 \mathrm{kDa}$.

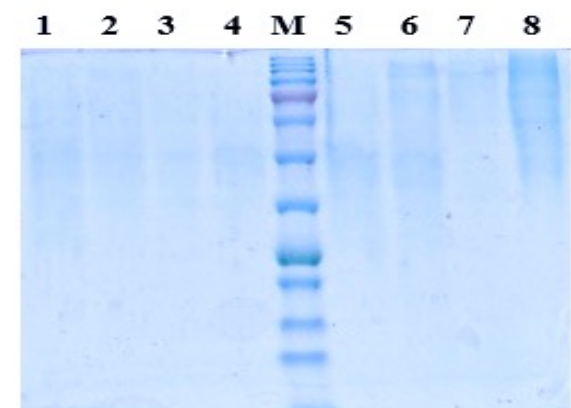

Figur 1. Elektroforegram hasil optimasi ekstraksi gelatin dengan SDS-PAGE.

Keterangan : $\mathrm{M}$ (Marker $245 \mathrm{kDa}), 1\left(24 \mathrm{jam} / 45^{\circ} \mathrm{C}\right), 2\left(32 \mathrm{jam} / 45^{\circ} \mathrm{C}\right)$, $3\left(48 \mathrm{jam} / 45^{\circ} \mathrm{C}\right), 4\left(56 \mathrm{jam} / 45^{\circ} \mathrm{C}\right), 5\left(24 \mathrm{jam} / 55^{\circ} \mathrm{C}\right), 6\left(32 \mathrm{jam} / 55^{\circ} \mathrm{C}\right), 7$ $\left(48 \mathrm{jam} / 55^{\circ} \mathrm{C}\right), 8\left(56 \mathrm{jam} / 55^{\circ} \mathrm{C}\right)$.

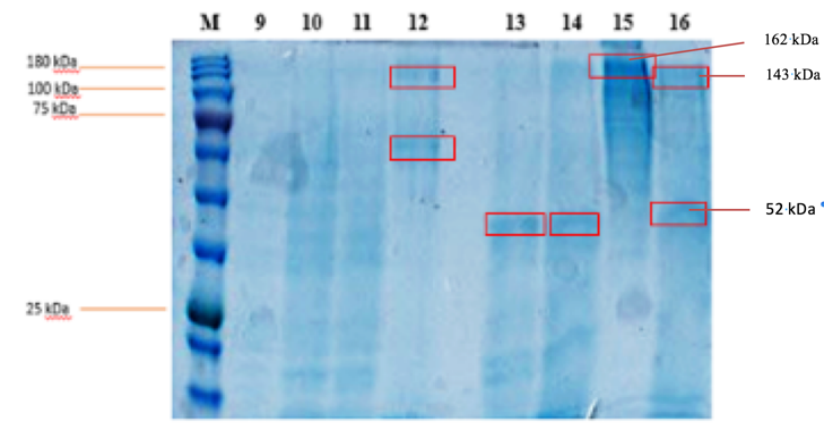

Figur 2. Elektroforegram hasil optimasi ekstraksi gelatin dengan SDS-PAGE.

Keterangan : $\mathrm{M}$ (Marker $245 \mathrm{kDa}), 9\left(24 \mathrm{jam} / 65^{\circ} \mathrm{C}\right), 10\left(32 \mathrm{jam} / 65^{\circ} \mathrm{C}\right)$ $11\left(48 \mathrm{jam} / 65^{\circ} \mathrm{C}\right), 12\left(56 \mathrm{jam} / 65^{\circ} \mathrm{C}\right), 13\left(24 \mathrm{jam} / 75^{\circ} \mathrm{C}\right), 14 \quad(32$ jam $\left./ 75^{\circ} \mathrm{C}\right), 15\left(48 \mathrm{jam} / 75^{\circ} \mathrm{C}\right), 16\left(56 \mathrm{jam} / 75^{\circ} \mathrm{C}\right)$.

Perhitungan bobot molekul diperoleh dari hasil perkalian berat molekul (BM) protein standar dengan nilai faktor retensi (Rf). Faktor retensi diperoleh dari pembagian jarak pita dengan berat molekul protein standar. Nilai $R_{f}$ dari marker protein didapatkan nilai $R^{2}$ $=0,9564$, semakin mendekati 1 maka persamaan regresi linier semakin menunjukan kepastian dari berat molekulnya. Setelah itu bobot molekul dapat dihitung melalui persamaan regresi linier dari marker protein yakni $y=-1,444 x+2,2649$. Kurva regresi linier dapat dilihat pada Figur 3.

Selanjutnya, gelatin dengan pre-treatment 48 jam dengan suhu main extraction $75^{\circ} \mathrm{C}$ dilakukan produksi skala besar untuk ke tahap analisis fisiko-kimia. Pengujian fisiko-kimia gelatin yang telah melalui proses main extraction di saring menggunakan kertas saring dan diletakan di dalam refrigerator pada suhu $4-10^{\circ} \mathrm{C}$ selama \pm 12 jam. Selanjutnya, gelatin cair dikeringkan dengan menggunakan dehydrator pada suhu $60^{\circ} \mathrm{C}$ selama \pm 3 jam menggunakan plastik mika, kemudian 
gelatin yang telah mengering dilakukan analisis fisik dan kimia.

Tabel 1. Perhitungan Retention Factor (RF) Hasil SDS-PAGE menggunakan Protein Marker $245 \mathrm{kDa}$

\begin{tabular}{|c|c|c|c|}
\hline $\begin{array}{l}\text { MW Marker } \\
(\mathrm{kDa})\end{array}$ & $\begin{array}{l}\text { log MW } \\
\text { Marker }\end{array}$ & $\begin{array}{l}\text { Panjang pita } \\
(\mathrm{cm})\end{array}$ & RF \\
\hline 245 & 2,389 & 0,2 & 0,0377 \\
\hline 180 & 2,255 & 0,3 & 0,0566 \\
\hline 140 & 2,146 & 0,4 & 0,0755 \\
\hline 100 & 2,000 & 0,6 & 0,1132 \\
\hline 75 & 1,875 & 1 & 0,1887 \\
\hline 60 & 1,778 & 1,4 & 0,2642 \\
\hline 45 & 1,653 & 2 & 0,3774 \\
\hline 35 & 1,544 & 2,7 & 0,5094 \\
\hline 25 & 1,398 & 3,5 & 0,6604 \\
\hline 20 & 1,301 & 3,8 & 0,7170 \\
\hline 15 & 1,176 & 4,4 & 0,8302 \\
\hline 10 & 1,000 & 4,8 & 0,9057 \\
\hline 5 & 0,699 & 5,1 & 0,9623 \\
\hline \multirow{2}{*}{\multicolumn{2}{|c|}{ Sampel nomor 12}} & 0,4 & 0,0755 \\
\hline & & 1,4 & 0,2642 \\
\hline \multicolumn{2}{|c|}{ Sampel nomor 13} & 2,5 & 0,4717 \\
\hline \multicolumn{2}{|c|}{ Sampel nomor 14} & 2,5 & 0,4717 \\
\hline \multicolumn{2}{|c|}{ Sampel nomor 15} & 0,2 & 0,0377 \\
\hline \multirow{2}{*}{\multicolumn{2}{|c|}{ Sampel nomor 16}} & 0,4 & 0,0755 \\
\hline & & 2 & 0,3774 \\
\hline
\end{tabular}

Keterangan : Panjang gel 5,3 cm

Tabel 2. Perhitungan Bobot Molekul Protein Gelatin

\begin{tabular}{cccc}
$\begin{array}{c}\text { Sampel } \\
\text { Nomor }\end{array}$ & $\begin{array}{c}\text { Nilai Rf } \\
(\mathrm{x})\end{array}$ & Nilai y & $\begin{array}{c}\text { Bobot } \\
\text { Molekul }(\mathrm{kDa})\end{array}$ \\
\hline 12 & 0,0755 & 2,1559 & 143 \\
& 0,2642 & 1,8834 & 76 \\
13 & 0,4717 & 1,5838 & 38 \\
14 & 0,4717 & 2,1559 & 38 \\
15 & 0,0377 & 2,2104 & 162 \\
16 & 0,0755 & 2,1559 & 143 \\
& 0,3774 & 1,7199 & 52 \\
\hline
\end{tabular}

Tabel 3. Komposisi gel untuk SDS- PAGE

\begin{tabular}{lcc}
\hline \multicolumn{1}{c}{ Senyawa kimia } & $\begin{array}{c}\text { Separating gel } \\
10 \%\end{array}$ & $\begin{array}{c}\text { Konsentrat gel } \\
3,9 \%\end{array}$ \\
\hline $1,5 \mathrm{M}$ Tris $\mathrm{HCl} \mathrm{pH} 8,8$ & $1,875 \mathrm{ml}$ & - \\
$0,5 \mathrm{M}$ Tris $\mathrm{HCl} \mathrm{pH} \mathrm{6,8}$ & - & $0,625 \mathrm{ml}$ \\
$44 \%$ Akrilamid & $1,681 \mathrm{ml}$ & $0,244 \mathrm{ml}$ \\
$2 \mathrm{H}_{2} \mathrm{O}$ & $3,94 \mathrm{ml}$ & $1,61 \mathrm{ml}$ \\
$10 \%$ APS & $25 \mu \mathrm{l}$ & $12,5 \mu \mathrm{l}$ \\
TEMED & $2,25 \mu \mathrm{l}$ & $2,5 \mu \mathrm{l}$ \\
Total & $7,5 \mathrm{ml}$ & $2,5 \mathrm{ml}$ \\
\hline
\end{tabular}

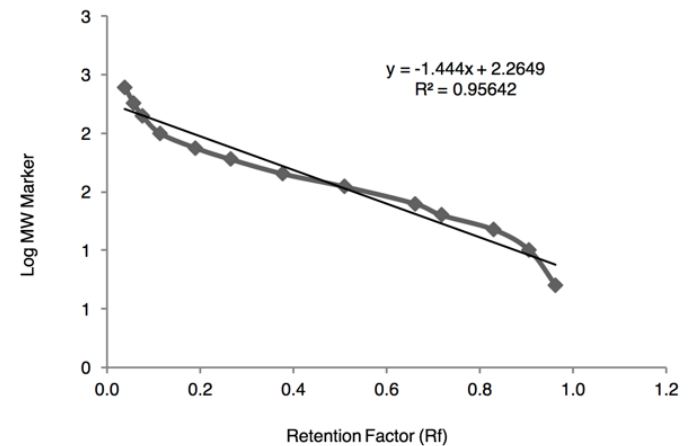

Figur 3. Kurva Regresi Linier Bobot Molekul Protein Marker
Derajat Keasaman $(\mathrm{pH})$

Derajat keasaman $(\mathrm{pH})$ merupakan salah satu aspek dari parameter yang diterapkan dalam penentuan standar mutu gelatin. Pengukuran nilai $\mathrm{pH}$ menggunakan alat $\mathrm{pH}$ meter sebagaimana tampil pada Tabel 4. Menurut Iqbal et al. (2015) pengukuran nilai pH penting dilakukan karena $\mathrm{pH}$ larutan mempengaruhi sifat-sifat gelatin lainnya seperti viskositas, kekuatan gel dan berpengaruh juga terhadap aplikasi gelatin dalam produk. Hasil uji pH gelatin tulang ikan patin adalah 4,462, nilai tersebut memenuhi Standar Nasional Indonesia (SNI) 06-3735 (1995) dan standar GMIA (2012).

Tabel 4. Hasil karakteristik fisik gelatin tulang ikan patin

\begin{tabular}{|c|c|c|c|c|}
\hline $\begin{array}{l}\text { Karakteristik } \\
\text { Fisik }\end{array}$ & $\begin{array}{c}\text { Hasil } \\
\text { Penelitian }\end{array}$ & GMIA & $\begin{array}{c}\text { SNI 06- } \\
3735\end{array}$ & $\begin{array}{c}\text { lqbal et al } \\
\text { (2015) }\end{array}$ \\
\hline$\overline{\mathrm{pH}}$ & 4,46 & $3,8-6,0$ & $4,5-6,5$ & 4,2 \\
\hline $\begin{array}{l}\text { Kekuatan gel } \\
\text { (bloom) }\end{array}$ & $364,19 \pm 0,04$ & $75-300$ & - & 136,439 \\
\hline Viskositas (cP) & $3,83 \pm 0,08$ & $1,5-7,5$ & - & 3,025 \\
\hline
\end{tabular}

Kekuatan gel

Kekuatan gel adalah salah satu parameter dari tekstur suatu bahan dan merupakan gaya untuk menghasilkan deformasi tertentu. Hasil pengukuran kekuatan gel pada gelatin dari tulang ikan patin yang diperoleh yakni 364,19 bloom (Tabel 4). Kekuatan gel pada penelitian ini lebih besar dari penelitian Mahmoodani et al. (2014) yaitu 254,7 bloom dan penelitian Iqbal et al. (2015) yaitu 136,439 bloom.

Nilai kekuatan gel pada penelitian ini terbilang tinggi karena pengujian sampel dilakukan setelah proses gelatin diekstraksi dan dilakukan penyaringan dengan kertas saring dan dimasukan ke dalam refrigerator pada suhu $10^{\circ} \mathrm{C}$ selama $17 \pm 2$ jam (sampai gelatin cair telah membentuk gel), sehingga konsentrasi gelatin lebih pekat. Kekuatan gel merupakan sifat fisik gelatin yang berhubungan dengan aplikasi pada produk pangan. Nilai kekuatan gel gelatin untuk diaplikasikan ke dalam produk confectionery adalah $>175$ bloom (Damayanti, 2007).

\section{Viskositas}

Viskositas gelatin menunjukan daya aliran molekul dalam suatu larutan baik itu air, cairan organik sederhana dan suspensi encer. Sistem koloid dalam larutan dapat meningkat dengan cara mengentalkan cairan, sehingga terjadi absorbsi dan pengembangan koloid (Haris 2008). Pengujian viskositas dilakukan untuk mengetahui tingkat kekentalan gelatin sebagai larutan pada konsentrasi dan suhu tertentu. Menurut Setiawati (2009) viskositas berhubungan dengan berat molekul (BM) rata-rata gelatin dan distribusi molekul. Bobot molekul gelatin berhubungan langsung dengan panjang rantai asam amino. Semakin panjang rantai asam amino maka nilai viskositas akan semakin tinggi.

Nilai viskositas penelitian ini diperoleh $3,83 \mathrm{cP}$ (Tabel 4). Nilai viskositas penelitian ini lebih tinggi jika dibandingkan dengan penelitian lqbal et al. (2015) yaitu hanya sebesar 3,025 cP. Nilai viskositas ini memenuhi persyaratan standar GMIA (2012) yaitu 3,8-6,0 cP 
sedangkan Standar Nasional Indonesia (SNI) belum menentukan standardisasinya.

\section{Profil Tekstur}

Hasil profil tekstur gelatin tulang ikan patin pada penelitian yaitu kekenyalan $17,1 \mathrm{~g}$ yang didapat dari perkalian antara kekerasan dan kohesivitas. Daya kunyah sebesar $261,76 \mathrm{~g}$ yang didapat dari perkalian antara kekenyalan dan elastisitas. Daya kunyah (chewiness) yang dihasilkan pada penelitian ini lebih tinggi jika dibandingkan dengan penelitian Mahmoodani et al. (2014) yaitu $214,2 \mathrm{~g}$. Hasil profil tekstur gelatin tulang ikan patin dapat dilihat pada Tabel 5.

Tabel 5. Hasil profil tekstur gelatin tulang ikan patin

\begin{tabular}{lc}
\hline \multicolumn{1}{c}{ Karakteristik Fisik } & Hasil Penelitian \\
\hline Kekerasan (hardness) $(\mathrm{g})$ & 8 \\
Kohesivitas (cohesiveness) & 2,14 \\
Elastisitas (springiness) $(\mathrm{mm})$ & 15,29 \\
kekenyalan (gumminess) $(\mathrm{g})$ & 17,1 \\
Daya kunyah (chewiness) $(\mathrm{g})$ & 261,76 \\
\hline
\end{tabular}

Karakteritik Kimia Gelatin Tulang Ikan Patin

Karakterisasi fisiko-kimia gelatin menggunakan metode analisis proksimat yang terdiri atas kadar air, kadar abu, kadar protein, dan kadar lemak. Hasil analisis fisiko-kimia gelatin dibandingkan dengan Standar Nasional Indonesia (SNI) 06-3735 (1995) dan standar lain yaitu Gelatin Manufactures Institute of America (GMIA) dan dibandingkan dengan penelitian lqbal et al. (2015) tentang gelatin tulang ikan lele dumbo yang diekstraksi menggunakan asam sitrat, hal tersebut untuk mengetahui perbandingan hasil penelitian gelatin tulang ikan patin yang telah dilakukan.

\section{Kadar Air}

Pengujian terhadap kadar air dilakukan untuk mengetahui kandungan air dalam gelatin tulang ikan patin. Kadar air merupakan parameter penting dari suatu produk pangan, karena kadar air sangat erat hubungannya dengan waktu simpan gelatin. Kadar air gelatin tulang ikan patin yang dihasilkan dalam penelitian ini sebesar $7,72 \%$ (Tabel 6). Nilai ini lebih baik dari nilai kadar air dalam penelitian lqbal et al. (2015) yang mengekstraksi gelatin dari tulang ikan lele dumbo menggunakan asam sitrat sebesar 13,12\%. Kadar air dalam penelitian ini telah memenuhi standar dari SNI 06-3735 (1995) yaitu maksimal 16\%.

Tabel 6. Hasil karakteristik kimia gelatin tulang ikan patin (\%b/b)

\begin{tabular}{lcccc}
\hline Karakteristik & $\begin{array}{c}\text { Hasil } \\
\text { Penelitian }\end{array}$ & GMIA & SNI 06-3735 & $\begin{array}{c}\text { lqbal et } \\
\text { al. (2015) }\end{array}$ \\
\hline Kadar Air & $7,72 \pm 0,01$ & - & Maks. 16 & 13,12 \\
Kadar Abu & $0,38 \pm 0,08$ & $0,3-2,0$ & Maks. 3,25 & 12,10 \\
Kadar Protein & $58,70 \pm 0,01$ & - & - & 65,42 \\
Kadar Lemak & $2,79 \pm 0,06$ & - & - & - \\
\hline
\end{tabular}

\section{Kadar Abu}

Abu adalah zat anorganik sisa dari hasil pembakaran suatu bahan organik yang ada pada bahan pangan. Penentuan kadar abu merupakan salah satu cara untuk mengetahui kemurnian suatu bahan (lqbal et al., 2015). Tinggi atau rendahnya kadar abu suatu bahan disebabkan oleh kandungan mineral yang ada pada bahan baku.

Kadar abu dalam gelatin tulang ikan patin hasil penelitian ini adalah $0,38 \%$ (Tabel 6), kadar abu pada penelitian ini memenuhi standar SNI 06-3735 (1995) dan memenuhi standar GMIA (2012), sedangkan pada penelitian lqbal et al. (2015), kadar abu sangat jauh berbeda dengan hasil yang didapat maupun dengan standar yang ada yaitu $12,1 \%$. Kadar abu adalah salah satu parameter yang digunakan untuk melihat kualitas dan tingkat keberhasilan dari proses ekstraksi pada gelatin. Tahapan proses pre-treatment gelatin yang dilakukan adalah untuk menghilangkan mineral dalam tulang ikan patin, sehingga menghasilkan ossein yang selanjutnya diekstraksi menjadi gelatin.

Penelitian ini menunjukan bahwa proses pretreatment berlangsung dengan cukup baik sebab dilakukan pengadukan menggunakan shaker selama pre-treatment berlangsung, sehingga mineral yang terbawa tidak banyak saat penyaringan gelatin.

\section{Kadar Protein}

Gelatin sebagai salah satu jenis protein konversi yang dihasilkan melalui proses hidrolisis kolagen, tentunya memiliki kadar protein yang tinggi. Kadar protein menunjukan seberapa besar kandungam protein yang terdapat dalam suatu bahan pangan. Hasil pengujian kadar protein gelatin tulang ikan patin yang dihasilkan, yaitu sebesar $58,70 \%$ (Tabel 6). Nilai ini lebih rendah dari nilai kadar protein dalam penelitian lqbal et al (2015) yaitu $65,42 \%$. Perbedaan nilai kadar protein ini diduga karena perbedaan konsentrasi asam sitrat yang digunakan dalam pembuatan gelatin. Penetapan standar kadar protein belum ditetapkan dalam SNI dan GMIA, sehingga tidak dapat dibandingkan dengan standar yang ada.

\section{Kadar Lemak}

Penentuan kadar lemak berpengaruh terhadap mutu bahan selama penyimpanan. Gelatin yang bermutu tinggi diharapkan memiliki kandungan lemak yang rendah (Haris 2008). Hasil analisis uji kadar lemak gelatin tulang ikan patin sebesar 2,79\% (Tabel 6). Nilai ini lebih tinggi dari pada kadar lemak gelatin dari penelitian yang dilakukan oleh (Damayanti 2007) yaitu $1,83 \%$. Menurut Haris (2008) nilai kadar lemak yang cukup tinggi ini diakibatkan oleh lemak yang belum keluar secara maksimal pada saat proses degreasing. Kadar lemak yang cukup tinggi memungkinkan akan mempengaruhi mutu gelatin selama penyimpanan. Kandungan lemak akan lepas pada saat proses perendaman dengan asam sitrat dan pada saat ekstraksi. Pemanasan akan mengakibatkan kerusakan lemak sehingga lemak akan terpisah dengan tulang dan terapung dipermukaan. Hal ini diakibatkan juga semakin besarnya suhu, maka berat jenis lemak akan semakin menurun sehingga lemak akan melayang di permukaan. 


\section{Rendemen gelatin}

Rendemen merupakan parameter penting untuk menilai efektivitas produksi gelatin tulang ikan patin. Gelatin cair (filtrat gelatin) yang telah melalui proses penyaringan dikeringkan menggunakan food dehydrator dengan suhu $60^{\circ} \mathrm{C}$ selama $\pm 3-4$ jam. Gelatin yang sudah mengering, kemudian dikerik dan ditimbang untuk mengetahui rendemen gelatin tulang ikan patin.

Tabel 7. Rendemen Gelatin Tulang Ikan Patin

\begin{tabular}{ccccc}
\hline $\begin{array}{c}\text { Berat tulang } \\
\text { ikan }(\mathrm{g})\end{array}$ & $\begin{array}{c}\text { Berat } \\
\text { Ossein } \\
(\mathrm{g})\end{array}$ & $\begin{array}{c}\text { Berat Gelatin } \\
\text { Kering }(\mathrm{g})\end{array}$ & $\begin{array}{c}\text { Rendemen } \\
(\%)\end{array}$ & $\begin{array}{c}\text { Rerata } \\
(\%)\end{array}$ \\
\hline 100 & 81,786 & 5,109 & 6,24 & $6,14 \pm 0,02$ \\
150 & 127,721 & 7,714 & 6,04 & \\
\hline
\end{tabular}

Semakin besar nilai rendemen yang dihasilkan maka semakin efisien perlakuan yang diberikan. Nilai rendemen gelatin tulang ikan patin menggunakan asam sitrat $1 \%$ dengan lama pre-treatment 48 jam dan suhu main extraction $75^{\circ} \mathrm{C}$ yaitu $6,14 \%$ (Tabel 7 ), dan lebih besar jika dibandingkan penelitian lqbal et al. (2015) yaitu hanya sebesar $2,90 \%$ yang menggunakan asam sitrat 5,8\% dengan waktu pre-treatment 41 jam dan suhu ekstraksi $70^{\circ} \mathrm{C}$. Perbedaan rendemen yang dihasilkan karena jenis tulang ikan, kosentrasi asam sitrat yang digunakan, waktu pre-treatment dan main extraction yang berbeda.

Menurut Haris (2008) jumlah nilai rendemen dipengaruhi oleh konsentrasi larutan asam sitrat yang digunakan dalam perendaman. Tinggi konsentrasi larutan asam yang digunakan akan menyebabkan larutan perendaman semakin asam, sehingga ion $\mathrm{H}+$ yang menghidrolisis kolagen dari rantai triple helix menjadi rantai tunggal semakin banyak. Konsentrasi yang tinggi serta waktu perendaman yang lama diduga dapat mengurangi jumlah rendemen gelatin yang dihasilkan. Hal ini dikarenakan pada perlakuan tersebut ossein yang dihasilkan menjadi sangat lunak dan hancur sehingga menyebabkan banyak ossein yang hilang selama proses penetralan. Menurut Puspawati et al. (2015) perendaman dengan asam sitrat $1 \%$ merupakan proses perendaman yang paling efektif untuk menghasilkan gelatin dengan rendemen tinggi.

\section{Kesimpulan}

Hasil penelitian ekstraksi gelatin tulang ikan patin terbaik dengan asam sitrat $1 \%$ yaitu dengan waktu pretreatment 48 jam dan suhu main extraction $75^{\circ} \mathrm{C}$. Bobot molekul gelatin tulang ikan patin yang didapat yaitu 162 $\mathrm{kDa}$. Hasil rendemen gelatin yang didapatkan sebesar $6,14 \%$. Nilai $\mathrm{pH}$, kekuatan gel, daya kunyah, dan viskositas dapat terdeteksi dengan baik. Kadar air, kadar abu, kadar protein, dan kadar lemak juga dapat terkarakteristik dengan baik serta dapat dibandingkan dengan SNI 06-3735 dan GMIA.

\section{Ucapan Terima Kasih}

Penelitian ini disponsori oleh Indofood Riset Nugraha dalam rangka program penghargaan bagi peneliti unggul bidang pengembangan pangan.

\section{Daftar Pustaka}

Adiningsih, Y., Purwanti, T. 2015. Karakterisasi mutu gelatin ikan tenggiri (Scomberomorus commersonii) dengan perendaman menggunakan asam sulfat dan asam sitrat. Jurnal Riset Teknologi Industri 9(2): 149-156. DOI:10.26578/jrti.v9i2.1713.

Atma, Y. 2016. Pemanfaatan limbah ikan sebagai sumber alternatif produksi gelatin dan peptida bioaktif: Review. Prosiding Seminar Nasional Sains dan Teknologi, Jakarta: 8-9 November.

Atma, Y. 2017. Amino acid and proximate composition of fish bone gelatin from different warm-water species: A comparative study. IOP Conference Series: Earth and Environmental Science 58:1-5. DOI:10.1088/1755-1315/58/1/012008.

Atma, Y., Ramdhani, H. 2017. Gelatin extraction the indegenous pangasius catfish bone using pineapple liquid waste. Indonesian Journal of Biotechnology 22(2):86-91. DOI 10.22146/ ijbiotech.32472.

Association of Official Analytical (AOAC). 1995. Official Methods of Analysis $16 \mathrm{t}^{\mathrm{h}}$ Edition. Maryland (US): Association of Official Analytical Chemist.

Damayanti, D. 2007. Aplikasi gelatin dari tulang ikan patin pada pembuatan permen jelly. Data tidak dipublikasikan.

Fatimah, D., Jannah, A. 2009. Efektivitas penggunaan asam sitrat dalam pembuatan gelatin tulang ikan bandeng.(Chanos-chanos forskal). Alchemy 1(1): 7-15. DOI:10.18860/al.v0i0.1663.

Gelatin Manufactures Institute of America (GMIA). 2012. Gelatin Handbook. Gelatin Manufactures Institute of America [Internet]. [Diunduh 9 Oktober 2017. Tersedia pada: http://www.gelatingmia.com/images/GMIA_Manual_2012.pdf.

Haris, M.A. 2008. Pemanfaatan limbah tulang ikan nila (Oreochromis niloticus) sebagai gelatin dan pengaruh lama penyimpanan pada suhu ruang. Data tidak dipublikasikan.

Indrialaksmi, O. 2000. Pembuatan dan Karakterisasi Sifat Fisik Gelatin dari Kulit dan Tulang Ikan Cucut. Data tidak dipublikasikan.

lqbal, M., Anam, C., Ridwan, A. 2015. Optimasi rendemen dan kekuatan gel gelatin ekstrak tulang ikan lele dumbo (Clarias gariepinus sp.).Jurnal Teknosains Pangan 4(4): 8-16.

Karim, A.A., Bhat, R. 2009. Review Fish Gelatin: Properties. Challenges and prospects as an alternative to mammalian gelatins. Trends in Food Science and Technology 19: 644-656.

Mahmoodani, F., Ardekani, V.S., See, S.F., Yusop, S.M., Babji, A.S. 2014. Optimization and physical properties of gelatin extracted from pangasius catfish (Pangasius sutchi) bone. Journal Food Science and Technology 51(11): 3104-3113. DOI: 10.1007/ s13197-012-0816-7

Mariod, A.A., Adam, H.F. 2013. Review: Gelatin, source, extraction and industrial applications. Acta Scientiarum Polonorum Technologia Alimentaria 12(2): 135-147. 
Nurul, A.G., Sarbon, N.M. 2015. Effects of $\mathrm{pH}$ on functional, rheological and structural properties of eel (Monopterussp.) skin gelatin compared to bovine gelatin. International Food Research Journal 22(2): 572-583.

Puspawati, N.M., Widihati, I.A., Widana, I.N. 2015. Analisis komposisi asam amino dan pola protein gelatin halal dari kulit ayam broiler. Data tidak dipublikasikan.

Rahayu, F., Fithriyah, N.H. 2015. Waktu ekstraksi terhadap remdemen gelatin dari tulang ikan nila merah. Prosiding Seminar Nasional Sains dan Teknologi, Jakarta: 17 November.

Ratnasari, I., Yuwono, S.S., Nusyam, H., Widjanarko, S.B. 2013. Extraction and characterization of gelatin from different fresh water fishes as alternative sources of gelatin. International Food Research Journal 20(6): 3085-3091.

Santoso, C., Surti, T, Sumardianto. 2015. Perbedaan penggunaan konsentrasi larutan asam sitrat dalam pembuatan gelatin tulang rawan ikan pari mondol (Himantura gerrardi). Jurnal Pengolahan dan Bioteknologi Hasil Perikanan 4(2): 106-114.
Setiawati, I.H. 2009. Karakterisasi Mutu Fisika Kimia Gelatin Kulit Ikan Kakap Merah (Lutjanus sp.) Hasil Proses Perlakuan Asam. Data tidak dipublikasikan.

Shyni, K., Hema, G.S., Ninan, G., Mathew, S., Joshy, C.G., Lakshmanan, P.T. 2014. Isolation and characterization of gelatin from the skins of skipjack tuna (Katsuwonus pelamis), dog shark (Scoliodon sorrakowah), and rohu (Labeo rohita). Food Hydrocolloids 39: 68-76. DOI : 10.1016/ j.foodhyd.2013.12.008.

Standar Nasional Indonesia (SNI) 06-3735. 1995. Mutu dan Cara Uji Gelatin. Jakarta: Badan Standardisasi Nasional.

Syahraeni, Anwar, M., Hasri. 2017. Pengaruh konsentrasi asam sitrat dan waktu demineraliasi pada perolehan gelatin dari tulang ikan kakap merah (Lutjanus sp.). Analytical and Environmental Chemistry 2(1): 53-62.

Walker, J.M. 2009. SDS polyacrylamide gel electrophoresis of proteins. Di dalam: Walker JM, editor. The Protein Protocols Handbook. $3^{\text {rd }}$ Edition. UK: Human Press. hlm 177-186. 